\title{
Conceptualizing Willingness to Defend and to Fight for Own Country ${ }^{1}$
}

Dr. Māris Andžāns (ORCID: 0000-0002-4695-3929), Rīga Stradiņš University and Latvian Institute of International Affairs https://doi.org/10.25143/willingness_to_defend_2021_ISBN_9789934563997_14-17

Willingness to fight war(fare), willingness to fi gh t $\int \mathrm{r}$ or $\mathrm{n} o$ un try and willingness to defend one's own country has been the subject to various academic studies. The issue has been approached from different perspectives, though usually relying on the interpretation of quantitative data acquired via public polls.

The most comprehensive research in this field has been conducted by Inglehart, Puranen and Welzel, as summarized in their article of 2015. The article presents four hypotheses. First, in a cross-sectional aspect, societies with higher life opportunities and existential security level emphasize prochoice values and thus demonstrate lower willingness to risk their lives in wars. Second, in a longitudinal aspect, the stronger growth in pro-choice values, the sharper the decline in willingness to endanger their lives. Third, in a multi-level aspect, societies with more common pro-choice values inflict members of those societies with lower levels of willingness to imperil themselves. Fourth, in a historical aspect, humiliation in past wars decreases the willingness to fight. All in all, the authors argued that increased life opportunities contribute to higher valuation of lives and, accordingly, lead to a lower willingness to risk lives. ${ }^{2}$

Several other hypotheses deserve attention as well. Díez-Nicolás concluded that the level of national pride, as well as the level of confidence in national armed forces is the most accurate prognosticator for the willingness to fight for own country - the higher the national pride and confidence in national armed forces, the higher the willingness to fi ght for the country. According to him, this trend can be observed in countries with significant differences, an d it te nds to be stable ov er lo ng pe riods of 
time. ${ }^{3}$ Also, Puranen and Torgler have underlined the strong link between higher level of national pride and trust in armed forces, and the willingness to fight. Torgler also added the trust in governments and legal systems as indicators of higher levels. ${ }^{4}$

Several studies have noted that the willingness to fight for one's country significantly depends on the historical, social and political context. Previous research, also that of Inglehart, Puranen and Welzel, has found two groups of countries standing out amongst others - the World War Two Axis powers (Germany and Japan in particular) and the Nordic countries. In the former, willingness to fight is low, ${ }^{5}$ while in the latter it surpasses the predictions of other hypotheses and indicators. ${ }^{6}$ Inglehart, Puranen and Welzel (and Puranen in a separate article) have explained these findings with the lifestyles of the Nordics and the vicinity of Russia which results in associating defence of a state with defence and promotion of values. ${ }^{7}$ Similarly, Díez-Nicolás observed that entanglement in ongoing conflicts and external threats can raise the level of willingness. ${ }^{8}$

Studies have also assessed regional, cultural and socio-economic contexts as determinants. Díez Nicolás concluded that the highest willingness to fight can be observed in Asian Sino-Confucian, Islamic and Sub-Saharan countries, while the lowest in West European Catholic and Anglo-Saxon countries (Baltic states here were classified among West European Protestant countries). ${ }^{9}$ A WIN/Gallup International Global Survey from 2014 concluded that the highest willingness to fight for one's country is in the Middle East and Northern Africa, as well as in Asia (also among Muslims and Hindus in terms of religious affiliation), whereas it is the lowest in Western Europe and North America (also among Protestants). ${ }^{10}$ Furthermore, Anderson, Getmansky, and Hirsch-Hoefler concluded that in societies with higher income inequality the willingness to fight for one's own country is lower compared to those with lower inequality levels. ${ }^{11}$

Among research focusing on choices of individuals, it has often been observed that indicators such as gender and attitude towards the country are notable factors. While various studies tend to arrive at different conclusions on certain indicators, many have concluded that men are more likely to fight than women ${ }^{12}$ (some others note also a younger age ${ }^{13}$ and marital status ${ }^{14}$ ), as well as that individuals with higher national pride and trust in the armed forces are willing to fight ${ }^{15}$ (some also note the related 
trust in the government and legal system, as well as religiousness and ideological inclination towards the right). ${ }^{16}$ While the level of education has been discussed as a factor, Anderson, Getmansky, and Hirsch-Hoefler noted a lack of evidence for interrelationship between education of individuals and willingness to fight for country. ${ }^{17}$

Other literature has assessed the impact of socio-economic factors on individual's choices. Anderson and Hirsch-Hoefler ${ }^{18}$ and Anderson, Getmansky, and Hirsch-Hoefler evaluated the link between economic equality and willingness to fight. The latter research concluded that in societies with low levels of inequality there is no difference in willingness to fight among the rich and the poor. However, as inequality in society grows, rich people become less willing to fight compared to their poor counterparts (poorer individuals are more prone to mobilize to fight). ${ }^{19}$ Torgler assessed the impact of divergence between benefits and costs in willingness to go to war. He did not find sufficient evidence that calculation between benefits and costs significantly influences the choice of individuals. ${ }^{20}$

Finally, Horowitz and Levendusky in an experiment in the United States assessed the impact of conscription in supporting warfare. They concluded that mandatory service reduces public support for wars. The most likely explanation is self-interest of individuals, i.e., preference not to risk their own life as conscripts. ${ }^{21}$

\section{ENDNOTES}

${ }^{1}$ The chapter is an updated version of a fragment of a previous study - Māris Andžāns, and Andris Sprūds, "Three-Decade Evolution of the Willingness to Defend One's Own Country: the Case of the Baltic States," Lithuanian Annual Strategic Review 18, no. 1 (2020): 195-220.

2 Ronald F. Inglehart, Bi Puranen, and Christian Welzel, "Declining willingness to fight for one's country: The individual-level basis of the long peace," Journal of Peace Research 52, no. 4 (2015): 418, 421-2.

${ }^{3}$ Juan Díez-Nicolás, "Cultural Differences on Values about Conflict, War and Peace," in Religion, democratic values and political conflict, ed. Yilmaz Esmer, Hans-Dieter Klingemann, and Bi Puranen (Uppsala University, 2009): 264, 272.

${ }^{4}$ Bi Puranen, "Allegiance eroding: People's dwindling willingness to fight in wars," in The Civic Culture Transformed: From Allegiant to Assertive Citizens, ed. Russell J. Dalton, and Christian Welzel (New York: Cambridge University Press, 2015), 269, 276-7; Benno Torgler, "Why do people go to war?" Defence and Peace Economics 14, no. 4 (2003): 276.

${ }^{5}$ Inglehart et al., "Declining willingness to fight for one's country: The individual-level basis of the long peace," 420, 428; Bi Puranen, "Allegiance eroding: People’s dwindling willingness to fight in wars," 271; Díez-Nicolás, "Cultural Differences on Values about Conflict, War and 
Peace," 265; Torgler, "Why do people go to war?" 276; Christopher J. Anderson, Anna Getmansky, and Sivan Hirsch-Hoefler, "Burden sharing: income, inequality and willingness to fight," British Journal of Political Science (2018): 32.

${ }^{6}$ Inglehart et al., "Declining willingness to fight for one's country: The individual-level basis of the long peace," 420, 428; Bi Puranen, "Allegiance eroding: People's dwindling willingness to fight in wars," 271; Torgler, "Why do people go to war?" 276.

7 Inglehart et al., "Declining willingness to fight for one's country: The individual-level basis of the long peace," 420; Bi Puranen, "Allegiance eroding: People's dwindling willingness to fight in wars," 271.

${ }^{8}$ Díez-Nicolás, "Cultural Differences on Values about Conflict, War and Peace," 259, 261-2, 264.

9 Ibid. 262.

${ }^{10}$ WIN/Gallup International, WIN/Gallup International Global Survey Shows Three in Five Willing to Fight for Their Country, March 18, 2015, 3.

${ }^{11}$ Anderson et al. "Burden sharing: income, inequality and willingness to fight," 30-1.

${ }^{12}$ Inglehart et al., "Declining willingness to fight for one's country: The individual-level basis of the long peace," 28 (appendix); Torgler, "Why do people go to war?" 276; Bi Puranen, "Allegiance eroding: People's dwindling willingness to fight in wars,” 277; WIN/Gallup International, WIN/ Gallup International Global Survey Shows Three in Five Willing to Fight for Their Country, 1.

${ }^{13}$ WIN/Gallup International, WIN/Gallup International Global Survey Shows Three in Five Willing to Fight for Their Country, 1; Torgler, "Why do people go to war?" 276.

${ }^{14}$ Anderson et al., "Burden sharing: income, inequality and willingness to fight," 31.

${ }^{15}$ Inglehart et al., "Declining willingness to fight for one's country: The individual-level basis of the long peace," 28 (appendix); Bi Puranen, "Allegiance eroding: People's dwindling willingness to fight in wars," 277; Torgler, "Why do people go to war?" 276; Anderson et al. "Burden sharing: income, inequality and willingness to fight," 5, 31-2.

${ }^{16}$ Torgler, "Why do people go to war?" 276.

${ }^{17}$ Anderson et al., "Burden sharing: income, inequality and willingness to fight," 32.

${ }^{18}$ Christopher J. Anderson, and Sivan Hirsch-Hoefler, "Unequal sacrifice: Income, Inequality, and the Willingness to Fight Wars," Paper prepared for presentation at the Annual Meeting of the American Political Science Association, Washington, DC, September 2-5, 2010: 1-37.

${ }^{19}$ Anderson et al., "Burden sharing: income, inequality and willingness to fight," 30-1.

${ }^{20}$ Torgler, "Why do people go to war?" 261, 276.

${ }^{21}$ Michael C. Horowitz, and Matthew S. Levendusky, "Drafting Support for War: Conscription and Mass Support for Warfare," The Journal of Politics 73, no. 2, (May 2011): 532. 